\title{
АКТИВНІСТЬ ЦИТОЛІТИЧНИХ ПРОЦЕСІВ У ЩУРІВ ЗА УМОВ ХРОНІЧНОї НЕОПЛАСТИЧНОЇ ІНТОКСИКАЦІЇ ПІСЛЯ ЗАСТОСУВАННЯ ЦИТОСТАТИКІВ
}

\author{
๑Л. Є. Грицишин, Л. С. Фіра, П. Г. Лихацький \\ Тернопільський державний медичний університет імені І. Я. Горбачевського МОз України
}

РЕзЮМЕ. Штучно індуковані за допомогою певних канцерогенів пухлини у лабораторних тварин створюють можливість для дослідження різних аспектів канцерогенезу, які не можуть бути ефективно вивчені безпосередньо на людському організмі.

Мета - з'ясувати в динаміці зміни цитолітичних процесів за умов моделювання раку товстої кишки введенням 1,2-диметилгідразин гідрохлориду та після застосування цитостатика Кселоди.

Матеріал і методи. У щурів досліджували особливості розвитку цитолітичних процесів за умов індукованого раку товстої кишки, зумовленого введенням 1,2-диметилгідразину та після застосування цитостатика Кселоди. 1,2-диметилгідразин вводили підшкірно в дозі 7,2 мг 1 раз на тиждень впродовж 30 тижнів. Кселоду вводили внутрішньошлунково щоденно в дозі 134 мг/кг маси тіла тварини протягом 21 дня, починаючи відразу після 7-місячного моделювання онкопроцесу. Розвиток цитолітичних процесів оцінювали за активністю амінотрансфераз, лужної фосфатази та еритроцитарним індексом інтоксикації.

Результати. В умовах ДМГ-індукованої інтоксикації встановлено значне прогресуюче зростання активностей амінотрансфераз та лужної фосфатази у сироватці крові тварин протягом 7 місяців, а також підвищення відсотка проникності плазматичних мембран еритроцитів. Застосування Кселоди дещо посилювало зростання активності цих ензимів та еритроцитарного індексу інтоксикації, що вказує на відсутність позитивного впливу цитостатиків на мембранодеструктивні процеси в організмі тварин з неопластичною інтоксикацією.

Висновки. Отримані результати підтверджують гепатотоксичність цитостатика Кселоди, що потребує введення додаткових коригуючих чинників з метою усунення його побічної дії на печінку та стабілізації проникності клітинних мембран.

КлючовІ СлОВА: 1,2-диметилгідразин; цитолітичні процеси; цитостатики; еритроцитарний індекс інтоксикації; амінотрансферази.

Вступ. За даними Всесвітньої організації охорони здоров'я, за рівнем захворюваності та смертності у світі онкопатологія займає друге місце, поступаючись лише хворобам серцево-судинної системи. Щороку лікарі рєєструють по 10 млн нових хворих $[1,12,18]$.

Серед етіологічних факторів пухлин людини найважливіша роль належить чинникам хімічної природи - канцерогенам і модифікаторам канцерогенезу. Залежно від природи етіологічного фактора можна виділити хімічний, фізичний (радіаційний), вірусний канцерогенез, канцерогенез чужорідноготіла [2]. До групи хімічнихгенотоксичних канцерогенних речовин належать поліциклічні ароматичні вуглеводні (ПАВ), нітрозосполуки, мікотоксини, ароматичні аміни, у тому числі 1,2-диметилгідразину гідрохлорид (ДМГ) [2, 20].

Для моделювання колоректального канцерогенезу в експерименті у щурів широко використовують 1,2-диметилгідразин (ДМГ). При тривалому застосуванні цієї речовини пухлини виникають і в інших відділах кишечника, а також можуть метастазувати або ж виникати de novo в таких органах як лімфатичні вузли, печінка, селезінка [8].

Колоректальний рак займає третє місце в структурі смертності від злоякісних захворювань.
Близько 50 \% онкологічних хворих помирають впродовж 2 років від лімфогенного та гематогенного метастазування. Тяжка клінічна картина цього отруєння, відсутність специфічної терапії, висока летальність потребують глибокого вивчення цієї інтоксикації $[1,2]$.

У літературі $\epsilon$ повідомлення про те, що значна частина онкохворих гине від розвитку цитолітичних процесів і так званої ендогенної інтоксикації. Вивчення цього питання в умовах індукованого канцерогенезу $\epsilon$ одним із перспективних, оскільки онкопроцес супроводжується посиленням процесів катаболізму в тканинах з утворенням нових токсичних продуктів [16], які можуть деструктивно впливати на клітинні мембрани.

Відомо, що маркерами порушення цілісності клітинних мембран (маркерами цитолізу гепатоцитів) $є$ органо- і органелоспецифічні ензими, що з'являються в крові у значній кількості. Серед них інформативними $\epsilon$ амінотрансферази. Як відомо, вміст цитозольних ензимів у сироватці крові та позаклітинному просторі тканин $\epsilon$ відносно низьким. Пошкодження плазматичних мембран або підвищення клітинної проникності призводить до ряду змін всередині клітини та завершується пошкодженням клітинних органел і виходом ензимів з цитозолю. Їх вміст у сироватці крові вказує 
Огляди літератури, оригінальні дослідження, погляд на проблему, випадок з практики, короткі повідомлення на ступінь пошкодження плазматичних мембран клітини [10].

У зв'язку зі зростаючою частотою та поширеністю онкологічних захворювань травної системи у сучасному суспільстві гостро стоїть питання пошуку та дослідження ефективних та малотоксичних цитостатиків таргетної дії [14].

При злоякісних пухлинах спостерігають системне ураження організму продуктами розпаду пухлин та компонентами хіміотерапії. Хіміотерапія злоякісних пухлин - це не що інше як медикаментозно індукований критичний стан організму, оскільки всі хіміопрепарати є отрутою, яку застосовують з метою отримання циторедуктивного, цитостатичного чи цитоелімінативного ефекту [8].

Кселода (капецитабін) - перший представник принципово нового класу препаратів туморактивованих цитостатиків. Препарат перетворюється в 5-фторурацил (5-ФУ) безпосередньо в тканині новоутворення під дією специфічного пухлинного ензиму тимідинфосфорилази, що забезпечує високу протипухлинну активність і низьку системну токсичність [7].

Доцільним виявилось дослідити ефективність Кселоди за умов хронічної неопластичної інтоксикації, яка розвивається в умовах моделювання раку товстої кишки, а також вплив цього препарату на печінку за даної патології.

Метою нашого дослідження було з'ясувати в динаміці закономірності змін цитолітичних процесів за умов моделювання раку товстої кишки введенням 1,2-диметилгідразину та після застосування цитостатика Кселоди.

Матеріал і методи дослідження. Дослідження виконано на 60 статевозрілих білих щу-

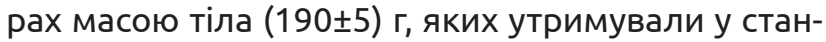
дартних умовах віварію ТНМУ імені І. Я. Горбачевського. Всі маніпуляції з експериментальними тваринами здійснювали із дотриманням правил «Європейської конвенції про захист хребетних тварин, що використовуються для дослідних та інших наукових цілей», а також згідно з «Науковопрактичними рекомендаціями з утримання лабораторних тварин та роботи з ними» $[5,13]$.

Піддослідні тварини були поділені на такі групи: контрольні - 6 тварин; експериментальна група тварин, уражених диметилгідразином (з них: виведені з експерименту через 1 місяць - 6 особин; виведені з експерименту через 2 місяці - 6 особин; виведені з експерименту через 3 місяці - 6 особин; 4, 5, 6, 7 місяців - 24 особини); група тварин, уражених диметилгідразином, яким вводили компоненти цитостатичної терапії - 12 щурів.

1,2-диметилгідразину гідрохлорид (ДМГ) (фірми SIGMA-ALDRICH CHEMIE виробництво Японія серія D161802) вводили, попередньо розвівши ізо-

тонічним розчином натрію хлориду. Канцероген вводили підшкірно в міжлопаткову ділянку в дозі 7,2 мг/кг (в розрахунку на діючу речовину) 1 раз на тиждень впродовж 30 тижнів, чітко по масі тварини з розрахунку 0,1 мл розчину ДМГ на 10 грам маси тіла [4]. Контролем для групи тварин з введенням ДМГ були щури, яким в аналогічну ділянку тіла щотижня підшкірно вводили 0,1 мл фізіологічного розчину на 10 грам маси тіла.

Як компонент цитостатичної терапії використовували препарат Кселода. Враховуючи шлях застосування препарату при лікуванні онкологічних хворих, Кселоду вводили внутрішньошлунково щоденно в дозі 134 мг/кг маси тіла тварини протягом 21 дня, починаючи відразу після 7-місячного моделювання онкопроцесу. Дозу цитостатика підбирали, користуючись інструкцією до застосування препарату та враховуючи видову чутливість тварин (перерахунок здійснювали за Ю. Р. Риболовлєвим) [9].

Експериментальне моделювання та забір крові для досліджень здійснювали в один час доби (10.00-12.00 год) у спеціальному приміщенні при температурі повітря 18-20 $\mathrm{C}$.

Ступінь інтоксикації організму оцінювали за еритроцитарним індексом інтоксикації (EII) - за кількістю поглинутого барвника (метиленового синього) еритроцитарними мембранами [3, 11]. Активність амінотрансфераз (АлАТ, АсАТ) та лужної фосфатази (ЛФ) досліджували з використанням напівавтоматичного біохімічного аналізатора Humalyzer 2000 та наборів реактивів фірми Human (Німеччина) $[15,19]$.

Обробку статистичних даних виконували за допомогою пакета програмного забезпечення SPSS-22 [17]. Отримані значення мали параметричний розподіл, тому різниця між групами була проаналізована відповідно до t-критерію Стьюдента та непараметричного критерію Вілкоксона для зв'язаних вибірок. Критерій $\chi^{2}$ був використаний для оцінки різниці між категоріальними даними. Різниця значень ймовірності була $p \geq 0,95$ (рівень значимості Р). Розбіжності вважали вірогідними при $\mathrm{p} \leq 0,05$.

Результати й обговорення. Поступлення В організм 1,2-ДМГ протягом семи місяців призводить до розвитку хронічної неопластичної інтоксикації, що було показано багатьма авторами $[2,4,8]$. Значна кількість утворених ендогенних токсинів деструктивно впливає на клітинні мембрани. Це підтверджується активацією цитолітичних процесів в організмі щурів, на що вказує активність мембранозалежних ензимів у сироватці крові.

Із літератури відомо, що більшість цитостатичних препаратів можуть викликати побічні ефекти в організмі, одним із проявів яких $є$ гепатотоксич- 
Огляди літератури, оригінальні дослідження, погляд на проблему, випадок з практики, короткі повідомлення ність $[7,8,16]$. Найефективніше ступінь ураження клітинних мембран відображається співвідношенням активності внутрішньоклітинних ензимів у клітині та поза їі межами, оскільки в нормі лише незначна їх кількість знаходиться в сироватці крові. Рівень активності ензимів корелює зі ступенем пошкодження, який може виражатися від патологічного посилення проникності мембрани клітин

до некрозу. Найбільшої уваги заслуговують органоспецифічні, або індикаторні ензими, які $є$ специфічними тільки для певного типу тканин [19].

У таблиці 1 наведено результати досліджень аланін- та аспартатамінотрансферази, а також лужної фосфатази у сироватці крові щурів, яким протягом 7 місяців вводили 1,2-ДМГ та після застосування цитостатика Кселоди.

Таблиця 1. Динаміка активності амінотрансфераз та лужної фосфатази у сироватці крові щурів з хронічною неопластичною інтоксикацією та після застосування Кселоди $(\mathrm{M} \pm \mathrm{m} ; \mathrm{n}=60)$

\begin{tabular}{|l|c|c|c|}
\hline \multicolumn{1}{|c|}{$\begin{array}{c}\text { Групи тварин / терміни ураження } \\
\text { диметилгідразином }\end{array}$} & АлАТ, мкат/л & АсАТ, мкат/л & ЛФ, мкат/л \\
\hline Інтактний контроль & $0,82 \pm 0,03$ & $1,27 \pm 0,03$ & $2,51 \pm 0,05$ \\
\hline 1 місяць ураження & $1,64 \pm 0,03^{*}$ & $1,59 \pm 0,03^{*}$ & $3,63 \pm 0,03^{*}$ \\
\hline 2 місяці ураження & $1,53 \pm 0,03^{*}$ & $1,91 \pm 0,03^{*}$ & $5,11 \pm 0,09^{*}$ \\
\hline 3 місяці ураження & $1,69 \pm 0,03^{*}$ & $2,11 \pm 0,03^{*}$ & $4,85 \pm 0,06^{*}$ \\
\hline 4 місяці ураження & $2,28 \pm 0,03^{*}$ & $2,81 \pm 0,04^{*}$ & $4,78 \pm 0,05^{*}$ \\
\hline 5 місяців ураження & $1,90 \pm 0,04^{*}$ & $3,22 \pm 0,02^{*}$ & $5,14 \pm 0,06^{*}$ \\
\hline 6 місяців ураження & $1,66 \pm 0,04^{*}$ & $3,71 \pm 0,04^{*}$ & $5,04 \pm 0,03^{*}$ \\
\hline 7 місяців ураження & $1,60 \pm 0,02^{*}$ & $3,89 \pm 0,03^{*}$ & $5,05 \pm 0,03^{*}$ \\
\hline 7 місяців ураження + Кселода (14 днів) & $1,63 \pm 0,06$ & $3,96 \pm 0,02$ & $5,13 \pm 0,04$ \\
\hline 7 місяців ураження + Кселода (21 день) & $1,66 \pm 0,02$ & $4,12 \pm 0,03^{* *}$ & $5,22 \pm 0,03^{* *}$ \\
\hline
\end{tabular}

Примітка. * - вірогідні зміни між тваринами інтактного контролю та ураженими диметилгідразином; ** - вірогідні зміни між ураженими тваринами та тваринами, які піддавались дії цитостатика (Кселоди).

У сироватці крові тварин з хронічною неопластичною інтоксикацією спостерігалось істотне $(p<0,05)$ підвищення досліджуваних ензимів протягом усього експерименту. Через 1 місяць від початку введення 1,2-ДМГ активність АлАТ у сироватці крові тварин підвищилась у 2 рази. Протягом усіх наступних термінів дослідження вона прогресивно зростала і до кінця експерименту залишалась вищою від показника інтактного контролю в 1,95 раза. Найвищим цей показник був на 4 місяць ураження (у 2,8 раза вище норми). Очевидно, у цей термін захисні резерви організму уже знизились, нагромадилась значна кількість токсичних метаболітів і активність ензиму в сироватці крові досягла свого максимального значення. Згодом організм поступово почав включати свої адаптаційні можливості, що викликало незначне зниження активності АлАТ, яка трималась практично на одному рівні до кінця експерименту. Застосування цитостатика Кселоди протягом 21 дня з моменту припинення застосування 1,2-ДМГ не привело до зниження активності ензиму. Він залишався на рівні уражених тварин.

Активність АсАТ аналогічно зростала протягом 7 місяців експерименту. Найвищим показник був з 4 місяця експерименту (у 2,2 раза) з наступним зростанням на $5,6,7$ місяці у 2,5; 2,9; 3,1 раза відповідно, порівняно з показником контрольної групи тварин. Можливо, таке прогресуюче зрос- тання активності АсАТ пов'язане зі стресовою ситуацією, у якій перебували тварини протягом 7-ми місяців, адже відомо, що АсАТ - ензим, який $\epsilon$ органоспецифічним для міокарда. Щотижневе введення токсиканта, очевидно, призводило до додаткового викиду у кров катехоламінів, зокрема адреналіну, підвищені дози якого можуть викликати цитоліз кардіоцитів та вихід АсАТ у кров. Застосування ураженим ДМГ тваринам цитостатика Кселоди привело до ще більшого зростання активності АсАТ, порівняно з групою тварин, яким цитостатик не вводили.

Підвищення активності амінотрансфераз у сироватці крові - маркерів цитолізу - можна розглядати як гіперферментемію, що може свідчити про підвищення проникності плазмолеми i, в деякій мірі, внутрішньоклітинних мембран клітин різних органів, зокрема печінки та серця. Ступінь підвищення амінотрансферазної активності сироватки крові вказує на вираження цитолітичного синдрому та зростання печінковоклітинної недостатності [15].

Про пошкодження мембранних структур гепатоцитів свідчать результати досліджень органоспецифічного ензиму (маркера холестазу) лужної фосфатази в сироватці крові.

Дослідження активності ЛФ впродовж 7 місяців показало зростання цього ензиму з найбільшими піками на 2 (у 2,1 раза), 5 (у 2,0 раза) та 7 (у 2,0 раза) місяці ураження. 
Огляди літератури, оригінальні дослідження, погляд на проблему, випадок з практики, короткі повідомлення

Оскільки ЛФ є органоспецифічним ензимом печінки, зростання якого у сироватці крові $\epsilon$ типовою ознакою холестазу, одержані результати слід розглядати як підтвердження ураження гепатоцитів із проявами запальних процесів, цитолізом та застоєм жовчі в жовчних капілярах і протоках, що супроводжує ураження паренхіми печінки [6].

При застосуванні Кселоди ураженим тваринам спостерігали достовірне зростання ЛФ $(p \leq 0,05)$ проти групи тварин з неопластичною інтоксикацією, які не отримували цитостатик.

Отримані результати з вивчення вищевказаних ензимів у щурів, яким застосовували Кселоду, можуть вказувати на гепатотоксичність використаного нами цитостатика.
Одним із способів діагностики ендогенної інтоксикації $\epsilon$ дослідження проникності мембран еритроцитів, а еритроцитарний індекс інтоксикації $\epsilon$ одним із ії маркерів. Мембрани зрілих еритроцитів розглядають як прототип плазматичних мембран усіх клітин організму, тому підвищення їх проникності (зростання EII) можна вважати характерним для клітин організму, що проявляється їх цитолізом та виходом з цитоплазми органота органелоспецифічних ензимів $[6,19]$.

У динаміці ураження 1,2-диметилгідразину гідрохлоридом спостерігали достовірне зростання Ell з 2 місяця введення у 1,6 раза, на 3 місяць - у 2,2 раза, на 4 місяць - у 3,1 раза, на 5, 6, та 7 місяці - у 3,4; 3,6; 3,7 раза відповідно, порівняно з аналогічним показником контрольної групи тварин (рис. 1).

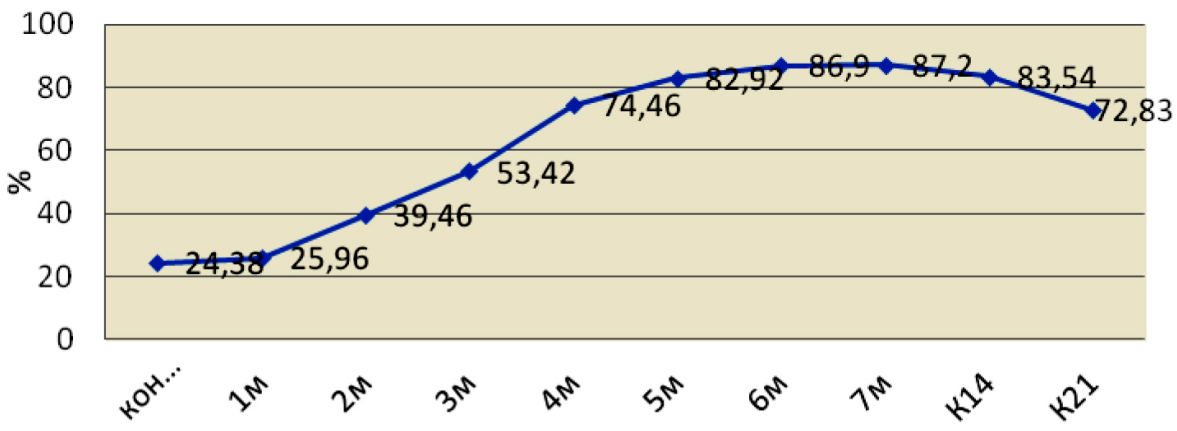

Рис. 1. Динаміка змін еритроцитарного індексу інтоксикації у тварин, уражених 1,2-диметилгідразином, та після застосування препарату Кселода.

Застосування цитостатика Кселоди протягом 21 дня призвело до зростання EII у 3 рази, що несуттєво відрізняється від аналогічного показника у групі тварин з чистим ураженням ДМГ.

Зростання рівня ендогенної інтоксикації може бути зумовлене не тільки нагромадженням у крові токсинів, а й порушенням співвідношення між окремими компонентами пулу речовин низької й середньої молекулярної маси. Однією з причин зміни проникності клітинних мембран під дією хімічного токсиканта може бути токсичний вплив його метаболітів на структурні компоненти саме мембран - як ліпідні, так і протеїнові [16].

Висновок. Введення 1,2-диметилгідразин гідрохлориду спричиняє підвищення активності органоспецифічних ензимів печінки та міокарда у сироватці крові, а також підвищення відсотка проникності еритроцитарної мембрани, що зу- мовлено розвитком синдрому цитолізу в експериментальних тварин і може призвести до їх загибелі. Застосування цитостатичного препарату Кселоди протягом 21 дня дещо посилило процеси цитолізу, на що вказувало ще більше зростання активності амінотрансфераз та лужної фосфатази у сироватці крові щурів. Отримані результати підтверджують гепатотоксичність цього засобу, що потребує введення додаткових коригуючих чинників з метою усунення його побічної дії на печінку та стабілізації проникності клітинних мембран.

Перспективи подальших досліджень. В умовах експериментальної ДМГ-індукованої інтоксикації на тлі застосування хіміотерапевтичних чинників вважаємо за доцільне додаткове введення гепатопротекторних засобів для усунення побічної дії цитостатичних препаратів. 
Огляди літератури, оригінальні дослідження, погляд на проблему, випадок з практики, короткі повідомлення ЛІТЕРАТУРА

1. Баныра О. Б. Маркеры опухолевого роста в диагностике рака / О. Б. Баныра, А. А. Строй, А. В. Шуляк // Экспериментальная и клиническая урология. - 2011. № 4. - С. 72-78.

2. Белицкий Г. А. Химический канцерогенез / Г. А. Белицкий // Современ. проблем. токсикологии. 2010. - № 2. - C. 5-21.

3. Влізло В. В. Лабораторні методи досліджень у біології, тваринництві та ветеринарній медицині / В. В. Влізло, Р. С. Федорук, І. Б. Ратич [та ін.]. - Львів : СПОЛОМ. - 2012. -764 С.

4. Дерягина В. П. Экспериментальное изучение действия Lentinus Edodes (Шиитаке) на рост опухоли у мышей на моделях трансплантационного и химического канцерогенеза / В. П. Дерягина, Н. И. Рыжова, А. Н. Разин // Российский онкологический журнал. - 2009. № 1. - С. 33-38.

5. Науково-практичні рекомендації з утримання лабораторних тварин та роботи з ними / Ю. М. Кожем'якін, О. С. Хромов, М. А. Філоненко, Г. А. Сайфетдінова. - К. : Авіцена, 2002. - 156 с.

6. Малахова М. Я. Эндогенная интоксикация как отражение компенсаторной перестройки обменных процессов в организме / М. Я. Малахова //Эфферентная терапия. - 2000. - Т. 6, № 4. - С. 3-14.

7. Паламарчук В. В. Обґрунтування застосування нових форм піримідинових антиметаболітів у комплексному лікуванні онкоотоларингологічних хворих / В. В. Паламарчук // Журнал вушних, носових і горлових хворо6. - 2007. - № 5. - С. 68-72.

8. Влияние вилона на неопластические процессы, индуцированные 1,2-диметилгидразином / Г. Б. Плисс, А. С. Мельников, В. В. Малинин, В. Х. Хавинсон // Вопросы онкологии. - 2005. - Т. 51, № 4. - С. 466-469.

9. Рыболовлев Ю. Р. Дозирование веществ для млекопитающих по константам биологической активности / Ю. Р. Рыболовлев, Р. С. Рыболовлев // Доклады AH CCCP. - 1979. - Т. 247, № 6. - С. 1513-1516.

\section{REFERENCES}

1. Banyra, O.B., Stroy, A.A., \& Shulyak, A.V. (2011). Markery opukholevogo rosta $v$ diagnostike raka [Markers of tumor growth in cancer diagnostics]. Eksperimentalnaya i klinicheskaya urologiya - Experimental and Clinical Urology, 4, 72-78 [in Russian].

2. Belitskyy, G. (2010). Khimicheskiy kantserogenez [Chemical carcinogenesis]. Sovremen. problemy toksikologiiModern Problems of Toxicology, 2, 5-21 [in Russian].

3. Vlizlo, V.V., Fedoruk, R.S., \& Ratich, I.B. (2012). Laboratorni metody doslidzhen u biolohii, tvarynnytstvi ta veterynarnii medytsyni [Laboratories and methods up to biology, veterinary medicine]. Lviv: SPOLOM [in Ukrainian].

4. Deryagina, V.P., Ryzhova, N.I., \& Razin, A.N. (2009). Eksperimentalnoye izucheniye deystviya LentinusEdodes (Shiitake) na rost opukholi u myshey na modelyakh trans-
10. Сорока Ю. В. Метаболические нарушения при хронической неопластической интоксикации и применении цитостатической терапии / Ю. В. Сорока // Медицина и образование в Сибири. - 2013. - № 2. - С. 16-19.

11. Тогайбаев А. А. Способ диагностики эндогенной интоксикации / А. А. Тогайбаев, А. В. Кургузкин, И. В. Рикун // Лаб. дело. - 1988. - № 9. - С. 22-24.

12. Cancer incidence and mortality patterns in Europe: Estimates for 40 countries in 2012 / J. Ferlay, E. Steliarova-Foucher, J. Lortet-Tieulent [et al.] //Eur. J Cancer. -2013.Vol. 49 (6). - P. 1374-403. DOI: 10.1016/j.ejca.2012.12.027.

13. Gross D. Ethics in animal-based research / D. Gross, R. Tolba // Eur. Surg. Res. - 2015. - Vol. 55 (1-2). - P. 43-57. DOI: $10.1159 / 000377721$.

14. Gür T. Tumor markers and biochemical parameters in colon cancer patients before and after chemotherapy / T. Gür, H. Demir, M. C. Kotan // Asian. Pac. J. Cancer Prev. - 2011. - Vol. 12 (11). - P. 3147-3150.

15. Aspartate aminotransferase (AST/GOT) and alanine aminotransferase (ALT/GPT) detection techniques / X. J. Huang, Y. K. Choi, H. S. Im [et al.] // Sensors (Basel). 2006. - Vol. 7 (6). - P. 756-782.

16. Johnson P. Oxidative stress: molecular, cellular and organ levels / P. Johnson, A. Boldyrev // Trivandrum (India): Research Singpost Pabl. - 2002. - 142 p.

17. Okeh U. Statistical problems in medical research / U. Okeh // East Afr. J. Public Health. - 2009. - Vol. 6, Suppl. 1. - P. 1-7.

18. Siegel R. Cancer statistics / R. Siegel, D. Naishadham, A. Jemal // Cancer Journal for Clinicians. - 2013. Vol. 63 (1). - P. 11-30. doi: 10.3322/caac.21166.

19. Tarrant J. Use of optimized aminotransferase methods in regulated preclinical studies / J. Tarrant, D. Meyer, P. Katavolos // Vet. Clin. Pathol. - 2013. - Vol. 42 (4). P. 535-538. DOI: 10.1111/vcp.12082.

20. Weiss R. B. Miscellaneous Toxicities, Chapter 54.8 / R. B. Weiss, S. Hellman, S. A. Rosenberg // Cancer: principles and practiceofoncology, 7th ed. Philadelphia: LippincottWilliams\&Wilkins. -2005 . -2802 p.

plantatsionnogo i khimicheskogo kantserogeneza [Experimental study of the effect of LentinusEdodes (Shiitake) on tumor growth in mice on models of transplantation and chemical carcinogenesis]. Rossiyskiy onkologicheskiy zhurnal-Russian Journal of Oncology, 1, 33-38 [in Russian].

5. Kozhemiakin, Yu.M., Khromov, O.S., Filonenko, M.A., \& Saifetdinova, H.A. (2002). Naukovo-praktychni rekomendatsii z utrymannia laboratornykh tvaryn ta roboty z nymy [Scientific and practical recommendations for the maintenance of laboratory animals and work with them]. Kyiv: Avitsena [in Ukrainian].

6. Malakhova, M.Ya. (2000). Endogennaya intoksikatsiya kak otrazheniye kompensatornoy perestroyki obmennykh protsessov v organizme [Endogenous intoxication as a reflection of compensatory reorganization of metabolic 
Огляди літератури, оригінальні дослідження, погляд на проблему, випадок з практики, короткі повідомлення processes in the body]. Efferentnaya terapiya - Efferent Therapy, 4, 3-14 [in Russian].

7. Palamarchuk, V.V. (2007). Obhruntuvannia zastosuvannia novykh form pirymidynovykh antymetabolitiv $u$ kompleksnomu likuvanni onkootolarynholohichnykh khvorykh [Substantiation of the application of new forms of pyrimidine antimetabolites in the complex treatment of oncotolaryngologic patients]. Zhurnal vushnykh, nosovykh $i$ horlovykh khvorob - Journal of the Ear, Nasal and Throat Diseases, 5, 68-72 [in Ukrainian].

8. Pliss, G.B., Melnikov, A.S., Malinin, V.V., \& Khavinson, V.Kh. (2005). Vliyaniye vilona na neoplasticheskiye protsessy, indutsirovannyye 1,2-dimetilgidrazinom [The effect of Vilon on neoplastic processes induced by 1,2-dimethylhydrazine]. Voprosy onkologii - Issues of Oncology, 51 (4), 466-469 [in Russian].

9. Rybolovlev, Yu.R., \& Rybolovlev, R.S. (1979). Dozirovaniye veshchestv dlya mlekopitayushchikh po konstantam biologicheskoy aktivnosti [Dosing of substances for mammals according to the constants of biological activity]. Doklady AN SSSR - Reports of the Academy of Sciences of the USSR, 247 (6), 1513-1516 [in Russian].

10. Soroka, Yu.V. (2013). Metabolicheskiye narusheniya pri khronicheskoy neoplasticheskoy intoksikatsii i primenenii tsitostaticheskoy terapii [Metabolic disorders in chronic neoplastic intoxication and the use of cytostatic therapy]. Meditsina i obrazovaniye v Sibiri-Medicine and Education in Siberia, 2,16-19 [in Ukrainian].

11. Togaybayev, A.A., Kurguzkin, A.V., \& Rikun, I.V. (1988). Sposob diagnostiki endogennoy intoksikatsii [A method for diagnosing of endogenous intoxication]. Lab. delo-Laboratory Business, 9, 22-24 [in Russian].

12. Ferlay, J., Steliarova-Foucher, E., Lortet-Tieulent, J., Rosso, S., Coebergh, J.W., Comber, H., Forman, D, \& Bray, F. (2013). Cancer incidence and mortality patterns in Europe: Estimates for 40 countries in 2012. Eur. J. Cancer, 49 (6), 1374-1403. doi: 10.1016/j.ejca.2012.12.027.

13. Gross, D., \& Tolba, R. (2015). Ethics in animal-based research. Eur. Surg. Res., 55 (1-2), 43-57. doi: 10.1159/ 000377721.

14. Gür, T., Demir, H., \& Kotan, M.C. (2011). Tumor markers and biochemical parameters in colon cancer patients before and after chemotherapy. Asian. Pac. J. Cancer Prev., 12 (11), 3147-3150.

15. Huang, X.J., Choi, Y.K., Im, H.S., Yarimaga, O., Yoon, E., \& Kim, H.S. Aspartate aminotransferase (AST/ GOT) and alanine aminotransferase (ALT/GPT) detection techniques. Sensors (Basel), 7 (6), 756-782.

16. Johnson, P., \& Boldyrev, A. (2002). Oxidative stress: molecular, cellular and organ levels. Trivandrum (India): Research Singpost Pabl.

17. Okeh, U. (2009). Statistical problems in medical research. East Afr. J. Public Health, (6). 1,1-7.

18. Siegel, R., Naishadham, D., \& Jemal, A. (2013). Cancer statistics. Cancer Journal for Clinicians, 63 (1), 11-30. doi: $10.3322 /$ caac. 21166.

19. Tarrant, J., Meyer, D., \& Katavolos, P. (2013). Use of optimized aminotransferase methods in regulated preclinical studies. Vet. Clin. Pathol., 42 (4), 535-558. doi: 10.1111/vcp.12082.

20. Weiss, R.B., Hellman, S., \& Rosenberg, S.A. (2005). Miscellaneous Toxicities, Chapter 54.8. Cancer: principles and practiceofoncology, 7 th ed. Philadelphia: Lippincott Williams\&Wilkins.

\section{АКТИВНОСТЬ ЦИТОЛИТИЧЕСКИХ ПРОЦЕССОВ У КРЫС В УСЛОВИЯХ ХРОНИЧЕСКОЙ НЕОПЛАСТИЧЕСКОЙ ИНТОКСИКАЦИИ ПОСЛЕ ПРИМЕНЕНИЯ ЦИТОСТАТИКОВ}

\section{ОЛ. Е. Грицишин, Л. С. Фира, П. Г. Лихацкий}

\section{Тернопольский национальный медицинский университет имени И. Я. Горбачевского МОз Украины}

РЕзЮМЕ. Искусственно индуцированные с помощью определенных канцерогенов опухоли у лабораторных животных создают возможность для исследования различных аспектов канцерогенеза, которые не могут быть эффективно изучены непосредственно на человеческом организме.

Цель - выяснить в динамике изменения цитологических процессов в условиях моделирования рака толстой кишки введением 1,2-диметилгидразина гидрохлорида и после применения цитостатика Кселоды.

Материал и методы. У крыс исследовали особенности развития цитологических процессов в условиях индуцированного рака толстой кишки, обусловленного введением 1,2-диметилгидразина и после применения цитостатика Кселоды. 1,2-диметилгидразин вводили подкожно в дозе 7,2 мг 1 раз в неделю в течение 30 недель. Кселоду вводили внутрижелудочно ежедневно в дозе 134 мг/кг массы тела животного в течение 21 дня, начиная сразу после 7-месячного моделирования онкопроцесса. Развитие цитологических процессов оценивали по активности аминотрансфераз, щелочной фосфатазы и эритроцитарному индексу интоксикации.

Результаты. В условиях ДМГ-индуцированной интоксикации установлен значительный прогрессирующий рост активностей аминотрансфераз и щелочной фосфатазы в сыворотке крови животных в течение 7 месяцев, а также повышение процента проницаемости плазматических мембран эритроцитов. Применение Кселоды несколько усиливало рост активности этих ферментов и эритроцитарного индекса интоксикации, что указывает на отсутствие положительного влияния цитостатиков на мембранодеструктивные процессы в организме животных с неопластической интоксикацией. 
Огляди літератури, оригінальні дослідження, погляд на проблему, випадок з практики, короткі повідомлення

Выводы. Полученные результаты подтверждают гепатотоксичность цитостатика Кселоды, что требует введения дополнительных корректирующих факторов с целью устранения его побочного действия на печень и стабилизации проницаемости клеточных мембран.

КЛЮЧЕВЫЕ СЛОВА: 1,2-диметилгидразин; цитолитические процессы; цитостатики; эритроцитарный индекс интоксикации; аминотрансферазы.

\section{ACTIVITY OF CYTOLYTIC PROCESSES IN RATS IN THE CONDITIONS OF CHRONIC NEOPLASTIC INTOXICATION AFTER APPLICATION OF CYTOSTATICS}

\section{@L. E. Grytcishin, L. S. Fira, P. H. Lykhatskyi}

\section{Horbachevsky Ternopil National Medical University}

SUMMARY. Artificially induced tumors in certain carcinogens in laboratory animals provide an opportunity to study various aspects of carcinogenesis that cannot be effectively studied directly on the human body.

The aim of the study - to find out the dynamics of changes in cytological processes in the simulation of colon cancer by the introduction of 1,2-dimethylhydrazine hydrochloride and after applying cytostatic Xeloda.

Material and Methods. In rats, the features of the development of cytological processes in conditions of induced colon cancer, caused by the administration of 1,2-dimethylhydrazine and after the use of Xeloda cytostatics, were investigated. 1,2-dimethylhydrazine was administered subcutaneously at a dose of $7.2 \mathrm{mg} / 1$ time per week for 30 weeks. Xeloda was administered intragastrically daily at a dose of $134 \mathrm{mg} / \mathrm{kg}$ of animal body weight for 21 days, starting immediately after a 7-month simulation of cancer process. The development of cytological processes was assessed by the activity of aminotransferases, alkaline phosphatase and erythrocyte intoxication index.

Results. Under conditions of DMH-induced intoxication, a significant progressive increase in the activities of aminotransferases and alkaline phosphatase in the blood serum of animals over 7 months was found, as well as an increase in the percentage of permeability of the red blood cell membranes. The use of Xeloda somewhat increased the activity of these enzymes and the erythrocyte index of intoxication, which indicates the absence of a positive effect of cytostatics on membrane-destructive processes in animals with non-plastic intoxication.

Conclusion. The obtained results confirm the Xetoda cytostatic toxicity, which requires the introduction of additional corrective factors in order to eliminate its side effects on the liver and stabilize the permeability of cell membranes.

KEY WORDS: 1,2-dimethylhydrazine; cytolytic processes; cytostatics; erythrocyte intoxication index; aminotransferase.

Отримано 2.05.2019 